\title{
Netpen liver disease (NLD) of salmonid fishes reared in sea water: species susceptibility, recovery, and probable cause
}

\author{
Michael L. Kent \\ Department of Fisheries and Oceans, Biological Sciences Branch, Pacific Biological Station, Nanaimo, British Columbia, \\ Canada V9R 5K6
}

\begin{abstract}
A severe toxicopathic liver disease of netpen-reared Atlantic salmon, Salmo salar, referred to as netpen liver disease (NLD), recurred in 3 consecutive summers in Port Townsend Bay, Washington, USA. The first histological changes associated with the disease are necrosis of individual hepatocytes and bile preductule cell proliferation. As NL.D progresses, diffuse necrosis, vacuolation and megalocytosis of the liver parenchyma are observed in affected fish. In 1988, NLD was also observed in chinook salmon, Oncorhynchus tshawtyscha, and Donaldson steelhead (rainbow $\times$ steelhead) trout, Salmo gairdneri, reared in Port Townsend Bay. The disease has now been observed in Atlantic salmon at 5 netpen sites in coastal waters in British Columbia. Canada. Netpen liver disease is most likely caused by a water-borne toxicant, the source and identity of which remain unknown. Chemical analysis of affected fish tissues, water and sediment from Port Townsend Bay has revealed no unusual concentrations of contaminants, and the sites in British Columbia are in apparently unpolluted waters. This suggests that the toxicant may be a natural toxin, possibly an algal one.
\end{abstract}

\section{INTRODUCTION}

A toxicopathic liver disease of unknown etiology caused high mortality in pen-reared Atlantic salmon, Salmo salar, in Port Townsend Bay, Washington, USA in 1986 and 1987 (Kent et al. 1988). Histopathological characteristics of the disease are diffuse hydropic degeneration, necrosis and megalocytosis of hepatocytes, perivascular cuffing, and melano-macrophage infiltration of the liver parenchyma (Kent et al. 1988). Henceforth, we refer to this apparently unique and specific disease as 'netpen liver disease' or NLD.

Kent et al. (1988) concluded that the cause of NLD was a water-borne toxicant. The histological appearance of the liver lesions was consistent with those of toxicopathic diseases and extensive examinations did not reveal an infectious agent associated with the condition. The source of the toxicant was most likely through the water column rather than the feed, because liver lesions were not detected in Atlantic salmon that were fed the same commercial diet but maintained at a different site.

Although there is strong presumptive evidence that
NLD is caused by a water-borne toxicant, its source and identity are unknown. Extensive chemical analyses of affected tissues, water, and sediment did not reveal its source or identity (Johnson 1988). In Port Townsend Bay, the only major source of industrial discharge is a pulp mill that discharges ca 12 million gallons per day into the bay. However, Atlantic salmon smolts exposed to high concentrations of this effluent for 4 mo did not develop NLD (Kent \& Elston 1989).

The commercial aquaculture company that reared the affected fish terminated netpen operations in Port Townsend Bay after the 1987 epizootic, and in 1988 another company introduced Atlantic salmon smolts at a third site in this bay. This farm also reared chinook salmon, Oncorhynchus tshawtyscha, and Donaldson steelhead trout (rainbow $\times$ steelhead), Salmo gairdneri. We report here on the prevalence and severity of NLD in salmonid and non-salmonid fishes from Port Townsend Bay, and on the occurrence of the disease at netpen facilities in British Columbia, Canada. Resolution of the liver lesions in affected fish that were transferred to clean sea water during the 1987 epizootic is also described. 


\section{MATERIALS AND METHODS}

Histology. The presence and severity of NLD was based on histological examinations of livers. Livers were collected from freshly killed fish, fixed in Davidson's or Bouin's solutions (Humason 1979), and processed for histological examination using standard techniques. Slides were stained with hematoxylin and eosin or Brown and Brenn Gram stain (Luna 1968).

Salmonids reared in Port Townsend Bay, 1988. On 7 June 1988, 1837 Atlantic salmon, Salmo salar, smolts were introduced to a seawater netpen at Site III (Fig. 1). These fish averaged $47 \mathrm{~g}$ at entry and ca $150 \mathrm{~g}$ when the study was terminated in February 1989. In October 1987, 138325 chinook salmon Oncorhynchus tshawtyscha were introduced to Site III and another group of 229647 chinook salmon were introduced on 16 June 1988. The chinook salmon introduced in October 1987 (large chinook) had averaged $439 \mathrm{~g}$ at the time of first sampling in June 1988 and weighed $786 \mathrm{~g}$ when last examined in October 1988. The chinook salmon introduced to seawater in June 1988 (small chinook) averaged $9 \mathrm{~g}$ at the first sampling on 8 July 1988 and $28 \mathrm{~g}$ when last examined in October 1988. In early June 1988, 4700 Donaldson rainbow trout were introduced to Site III. These fish averaged $100 \mathrm{~g}$ when introduced, and $480 \mathrm{~g}$ when sampled in September 1988 .

Fishes that were apparently healthy and showed no signs of other diseases were examined in this study. Fifteen fish from the Atlantic salmon group and 15 from each group of chinook salmon were examined monthly until October 1988 for the presence of NLD. The Atlantic salmon that survived the 1988 epizootic were sacrificed on 15 February 1989, and the livers of 15 of these fish were examined. Ten Donaldson rainbow trout Salmo gairdneri were examined on 12 September 1988. Mortality data were collected from these groups through December 1988 by fish farm personnel. Salinity ranged from 28 to $31 \mathrm{ppt}$ and temperature ranged from 8 to $12^{\circ} \mathrm{C}$ at Site III during the study period.

Non-salmonid fishes from enzootic waters. To determine if non-salmonid fishes were susceptible to the disease, fishes were collected from in or around netpens in Port Townsend during epizootics in 1987 and 1988 and the livers were examined histologically. Twenty Pacific herring Clupea harengus and 20 shiner perch Cymatogaster aggregata were collected from netpen Site II (Fig. 1) during an epizootic on 26 September 1987. Sixteen English sole Parophrys vetulus were collected by otter trawl close to the pens at Site II on 21 August 1987. Ten shiner perch were collected on 8 August 1988 and 15 shiner perch were collected on 12 September 1988 from a netpen at Site III.

Recovery after transfer to clean water. Fifty-one Atlantic salmon from the 1987 epizootic were transferred to the Battelle Marine Science Laboratory, Sequim, Washington, USA, to determine if fish transferred to water without the presumed toxicant recovered, and exhibited liver regeneration and neo-

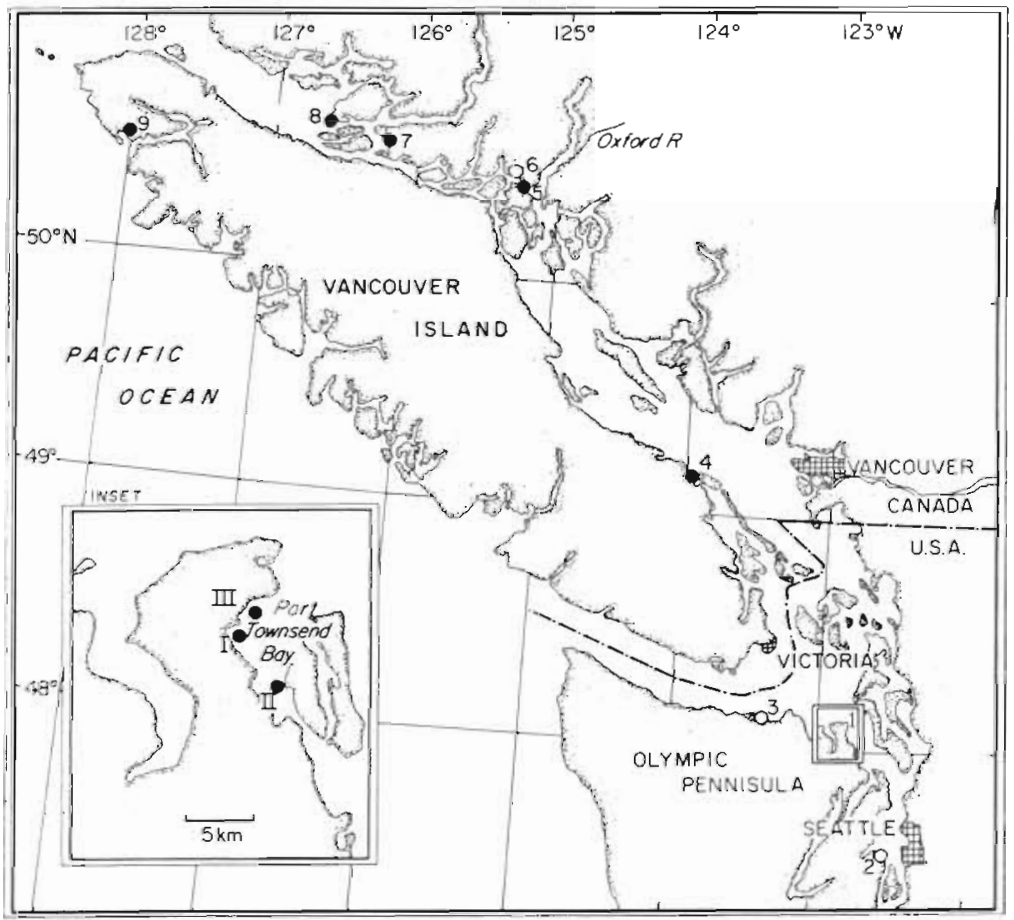

Fig. 1. Geographical distribution of netpen liver disease (NLD) in Atlantic salmon, Salmo salar, in British Columbia, Canada, and Washington, USA. ( $\bullet$ sites where the disease has been detected; ( ) sites where fish have been examined and disease has not been detected. Sites are (1) Port Townsend Bay, inset indicates sites (I to III) in bay were NLD has occurred. (2) National Marine Fisheries Service, Experimental Marine Station, Manchester, Washington; examined in 1986 and 1987 (3) Private fish farm near Port Angeles, Washington; examined from 1986 to 1988. (4) Pacific Biological Station; examined in July 1986. (5 to 8) Private netpen sites; examined from August to October 1988. (9) Private netpen site; examined in August 1987 
plastic lesions. The fish were maintained in an open system aquarium receiving sand-filtered seawater at 9 to $12^{\circ} \mathrm{C}$, with salinities between 28 and 30 ppt. Fish were fed daily with the same commercial diet used at Site II during the 1987 epizootic. Ten fish were examined at the time of transfer and samples of 5 fish each were examined at 1, 3, and 6 mo posttransfer (PT). At 9 mo PT the study was terminated and the remaining 17 fish were collected and examined.

To ensure that the unknown toxicant was absent from the water at Battelle during the experiment, 30 healthy Atlantic salmon from an unaffected netpen site (Site 3, Fig. 1) at Port Angeles, Washington were transferred to Battelle on 28 October 1987 and allowed to cohabit with the affected fish from Site III. The livers of 10 of these fish were examined by histology at the time of transfer and at 2 and 8 mo PT.

Geographical distribution of NLD. Atlantic salmon at 6 netpen sites in British Columbia (Fig. 1) were examined for the presence of the liver disease. Most examinations were conducted in the summer of 1988 , but fish collected in previous summers were used at 2 sites that did not maintain Atlantic salmon smolts in 1988. At least 15 fish were examined at each of these sites.

\section{RESULTS}

\section{Port Townsend Bay, Site III}

Mortality in salmonids

Mortality in Atlantic salmon smolts was high throughout the summer (Fig. 2) with a cumulative mortality of $65 \%$. Cumulative mortalities in large chinook (introduced in October 1987), small chinook (introduced in June 1988), and rainbow trout (introduced in June 1988) were 7,23 and $13 \%$, respectively.

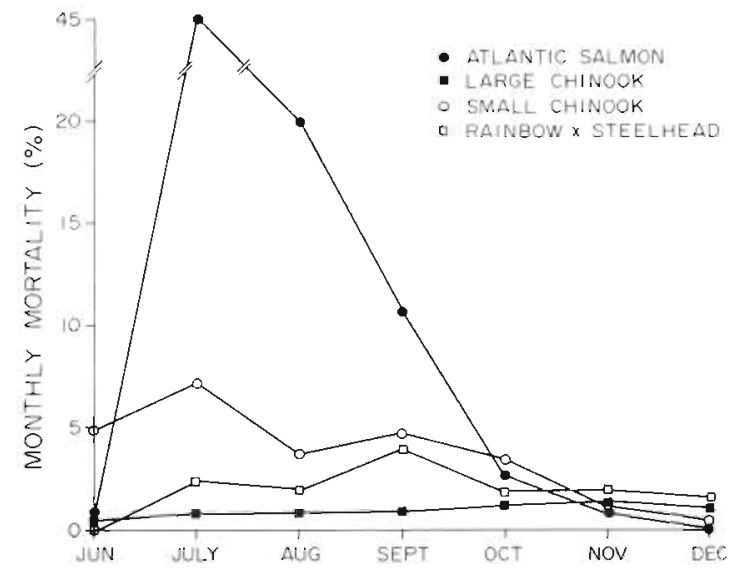

Fig. 2. Monthly mortality of Atlantic salmon Salmo salar, large chinook and small chinook Oncorhynchus tshawytscha and Donaldson steelhead trout (rainbow $\times$ steelhead trout) Salmo gairdneri maintained in netpens at Site III, Port Townsend Bay, Washington, USA in 1988

\section{Histology of salmonids}

Prevalence and severity of liver lesions associated with NLD in salmonids reared at Site III are reported in Table 1. NLD was detected in Atlantic salmon, rainbow trout and small chinook, while large chinook exhibited no histological signs of the disease. Mild lesions $(+)$ were characterized by proliferation of bile preductual cells, mild nuclear pleomorphism and individual necrotic hepatocytes scattered throughout the liver parenchyma (Figs. 3, 4), and were more prevalent early in the summer (Table 1). Moderate $(++)$ and severe $(+++)$ lesions were characterized by prominent nuclear pleomorphism leading to megalocytosis, diffuse necrosis and vacuolation of hepatocytes, perivascular cuffing by inflammatory cells and ceroid deposition in macrophages (Figs. 5, 6). Loss of normal tubulosinusoid architecture of the liver parenchyma was observed in concurrence

Table 1. Prevalence (\%) of liver lesions by severity $(0$ to +++$)$ in Atlantic salmon Salmo salar, small chinook Oncorhynchus tshawytscha and Donaldson rainbow trout Salmo gairdneri in netpens at Site III in Port Townsend Bay, Washington. $0=$ no lesions; $+=$ mild, $++=$ moderate,$+++=$ severe. Days: days after introduction to netpens; NE: no. fish examined

\begin{tabular}{|c|c|c|c|c|c|c|c|c|c|c|c|c|c|c|c|c|c|c|}
\hline \multirow[t]{2}{*}{ Date } & \multicolumn{6}{|c|}{ Atlantic salmon } & \multicolumn{6}{|c|}{ Chinook salmon } & \multicolumn{6}{|c|}{ Rainbow trout } \\
\hline & Days & 0 & + & ++ & +++ & NE & Days & 0 & + & ++ & +++ & NE & Days & 0 & + & ++ & +++ & NE \\
\hline 9 Jun 1988 & 2 & 0 & 0 & 0 & 0 & 15 & 0 & - & - & - & - & 0 & & - & - & - & - & 0 \\
\hline 8 Jul 1988 & 31 & 20 & 80 & 0 & 0 & 15 & 22 & 0 & 0 & 0 & 0 & 15 & & - & - & - & - & 0 \\
\hline 8 Aug 1988 & 62 & 30 & 30 & 35 & 5 & 17 & 53 & 93 & 7 & 0 & 0 & 15 & & - & - & - & - & 0 \\
\hline $12 \operatorname{Sep} 1988$ & 97 & 0 & 14 & 53 & 33 & 15 & 86 & 0 & 60 & 13 & 27 & 15 & $\sim 95$ & 70 & 0 & 20 & 10 & 10 \\
\hline 7 Oct 1988 & 122 & 0 & 20 & 35 & 45 & 15 & 113 & 7 & 60 & 27 & 6 & 15 & & - & - & - & - & 0 \\
\hline 15 Feb 1989 & 253 & 67 & 33 & 0 & 0 & 15 & 244 & - & - & - & - & 0 & & - & - & - & - & 0 \\
\hline
\end{tabular}



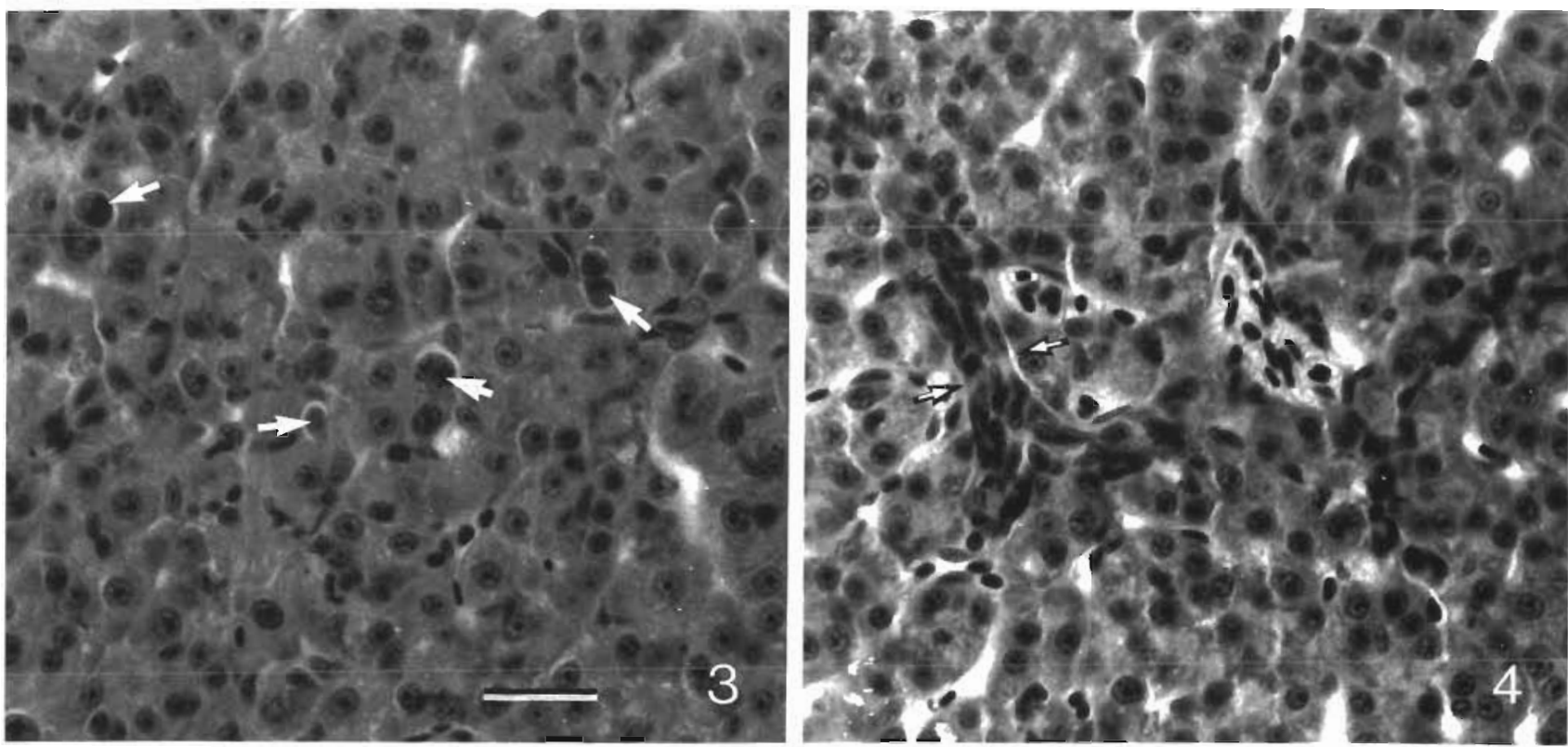

Figs. 3 and 4. Salmo salar. Early histological changes in livers with netpen liver disease (NLD); $H$ \& $E_{;}$scale bar $=20 \mu m$. Fig. 3. Individual necrotic hepatocytes (arrows) scattered throughout an otherwise normal liver parenchyma. Fig. 4. Proliferation of bile preductule cells (arrows)
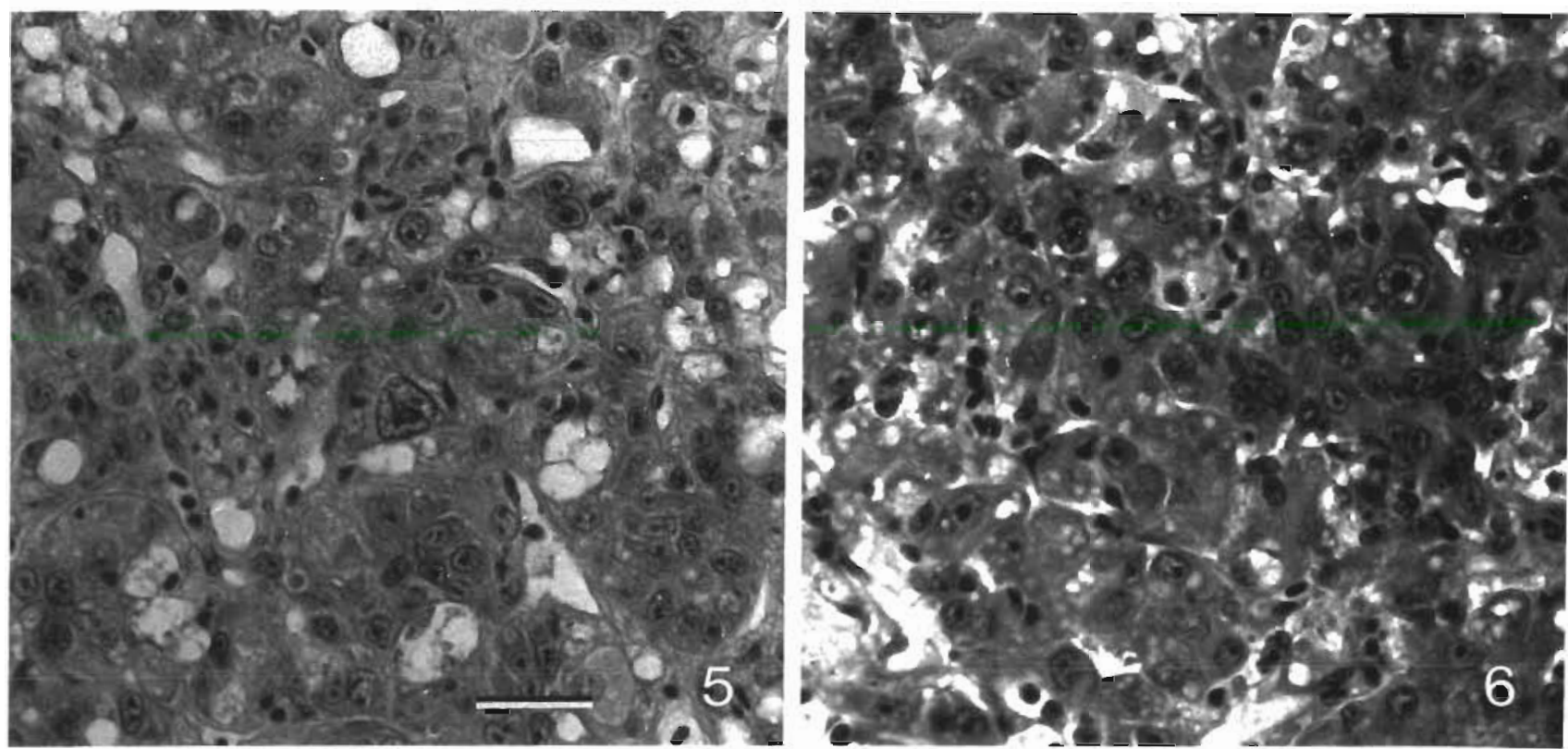

Figs. 5 and 6 . Oncorhynchus tshawtyscha and Salmo salar. Livers with netpen liver disease (NLD) exhibiting megalocytosis,

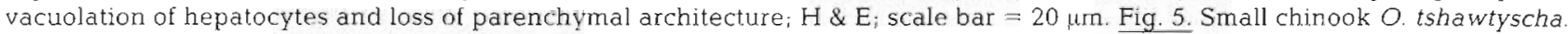
Fig. 6. Atlantic salmon $S$ salar liver from 1987 epizootic at time of transfer to clean water

with the severity of megalocytosis and nuclear pleomorphism. The lesions were very diffuse and the entire liver was affected, regardless of the severity of the lesions.

Multifocal granulomas, consistent with bacterial kidney disease ( $B K D)$, were observed in the liver of one Atlantic salmon collected on 12 September 1988, and small Gram-positive bacterial rods, suggestive of Renibacterium salmoninarum, were observed in granulomas stained with the Gram stain

Examination of Atlantic salmon collected in February 1989 showed marked recovery (Table 1). Livers appeared essentially normal, but 5 livers exhibited mild changes that consisted of occasional individual 
megalocytic hepatocytes and small melano-macrophage aggregates scattered throughout an otherwise normal liver parenchyma.

\section{Non-salmonid fishes}

Histological examination of shiner perch. English sole, and herring collected in Port Townsend Bay during epizootics of NLD showed no signs of the disease.

\section{Geographical distribution}

In addition to Port Townsend Bay, NLD was detected in Atlantic salmon reared at 5 netpen farms throughout British Columbia (Fig. 1).

\section{Recovery after transfer to clean sea water}

NLD was observed in the 10 Atlantic salmon examined when they were transferred from Site II to clean water at Battelle in September 1987. The livers appeared atrophied, pale and mottled. Histological examination revealed severe lesions prominent perivascular cuffing, megalocytosis, vacuolation and necrosis of hepatocytes and a loss of normal liver architecture was observed in all (Fig. 6).

Nine fish died within $1 \mathrm{wk}$ after transfer to Battelle.
These fish were not examined histologically. After 1 wk, the remaining 32 fish appeared healthy and no additional mortality occurred throughout the study.

At 1 mo PT, livers appeared grossly normal in the 5 fish examined. However, histological examination revealed pathological changes characteristic of NLD in all livers (Fig. 7). Although the livers exhibited areas of regeneration, the majority of the liver parenchyma had toxicopathic changes similar to those observed at the time of transport.

At 3 mo PT, livers of 4 of the 5 fish examined had almost completely regenerated. The livers exhibited normal tubulosinusoid architecture and most hepatocytes had normal nuclear morphology. However, megalocytic hepatocytes were scattered throughout the liver parenchyma (Fig. 8). The fifth liver continued to exhibit perivascular cuffing and had numerous melano-macrophage aggregates.

At 6 and 9 mo PT livers appeared essentially normal, but contained individual megalocytic hepatocytes. They were observed in small numbers in all of the 5 fish collected at 6 mo, and were observed in 9 of 17 livers collected at 9 mo PT. No neoplastic or preneoplastic lesions were detected in any livers.

The healthy Atlantic salmon transferred from Port Angeles (Site 3) and cohabited with affected fish remained normal throughout the study. Histological examination of these fish at 2 and 8 mo PT showed no signs of NLD.
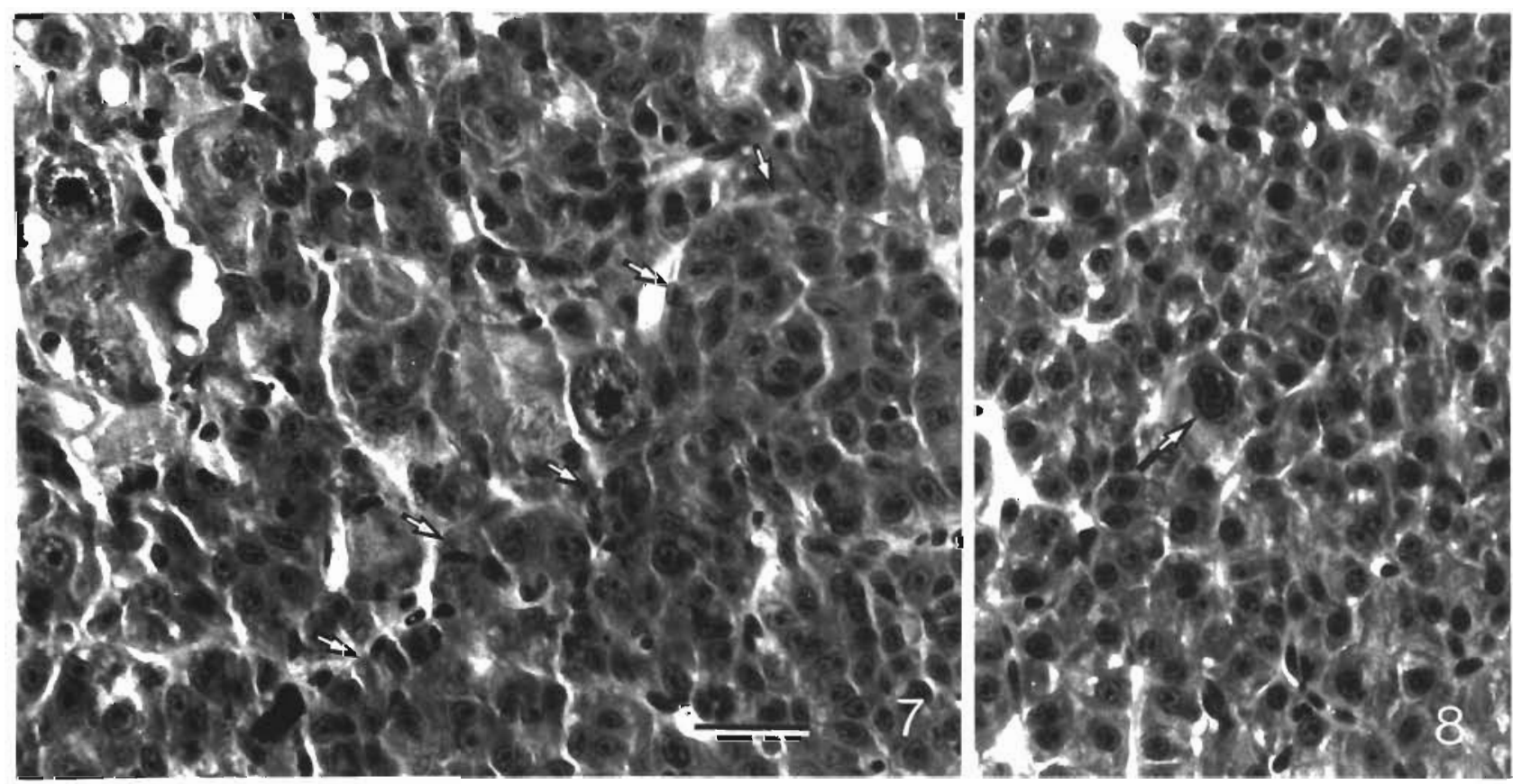

Figs. 7 and 8. Salmo salar. Regeneration of livers with netpen liver disease (NLD) following transfer to clean water; H \& $E_{;}$Scale bar $=20 \mu \mathrm{m}$. Fig. 7 . One month post transfer (PT), liver exhibits significant regeneration, but megalocytic and vacuolated hepatocytes are still present. Arrows: area of regeneration. Fig. 8. Three months PT, liver appears essentially normal, but individual megalocytes (arrow) are scattered throughout the parenchyma 


\section{DISCUSSION}

Netpen liver disease has occurred in Port Townsend Bay for 3 successive years, and its association with high mortality in Atlantic salmon indicates that it is a major factor in preventing the rearing of this species in netpens in this bay. Observations of NLD in 1986 and 1987 indicate that the disease is a summer phenomenon (Kent et al. 1988). Although Atlantic salmon are usually introduced to netpens in late spring, time of seawater entry does not appear to affect the seasonality of the disease. In 1987, smolts were introduced to netpens in early March, whereas in 1988 smolts were introduced in early June. Not withstanding this, pathological changes indicative of NLD were first observed in both years in late June to early July. Furthermore, fish introduced to an experimental netpen at Site II on 29 August 1988 exhibited liver lesions consistent with NLD 14 d later (Kent \& Elston 1989), indicating that lesions occur shortly after exposure to the unknown toxicant.

Although mortalities continued throughout fall and winter during the 1986 epizootic, the livers of affected fish exhibited marked regeneration (Kent et al. 1988). Similar recoveries were observed in the 1988 epizootic. Mortalities in the Atlantic salmon declined dramatically in the late fall (Fig. 1), and histological examination of surviving fish in February 1989 indicated that the livers had almost completely recovered. This suggests that the toxicant is not present in high concentration in Port Townsend Bay in late fall and winter. Therefore, the toxicant is apparently first present at affected sites, or at least in Port Townsend Bay, approximately in June, persists at least through August, and diminishes in fall and winter. The severity and prevalence of the liver lesions during the summer and early fall, and the concurrence of liver regeneration with decreased mortality in the winter indicate that NLD was a significant cause of mortality in the Atlantic salmon in 1988.

Severely affected fish from the 1988 epizootic exhibited lesions identical to those of the 1986 and 1987 epizootics described by Kent et al. (1988). Characteristic of NLD, livers of these fish showed prominent megalocytosis, necrosis and perivascular cuffing. However, in mildly affected fish early in the disease, vacuolation and necrosis of hepatocytes were not always predominant features, and proliferation of preductule cells was often observed. Bile preductule cell proliferation was not previously associated with NLD (Kent et al. 1988) and this difference may be due to the health status of the fish. Whereas livers of moribund fish were examined during the 1986 and 1987 epizootics, apparently healthy fish were examined in the present study. It is likely that the severe necrotic changes in the livers of moribund fish examined in 1986 and 1987 masked the proliferative changes in bile ductules.

Livers of Atlantic salmon with severe NLD recovered after they were transferred to clean water at Battelle. Salinities and water temperature at Battelle and Port Townscnd were similar, but several fish died shortly after transfer. This was most likely due to handling and transport stress. Although livers exhibited substantial hepatocellular regeneration and recovery 1 mo PT, megalocytic hepatocytes persisted until the study was terminated at $9 \mathrm{mo}$. Megalocytosis is commonly interpreted as a failure of cell division, resulting in polyploid hepatocytes as a consequence of disrupted mitosis (Wales 1967, Sinnhuber et al. 1977). Its presence is used as an early indication of hepatocarcinogenhepatotoxin exposure in the natural environment (Myers et al. 1987). Our transfer study has demonstrated that megalocytic hepatocytes can persist for many months after the toxicant is removed and the liver has regenerated. The presence of these cells in an otherwise normal liver can therefore be used as an indication of an earlier liver intoxication. Based on numerous studies of hepatocarcinogensis in fishes (Hendricks 1982, Hendricks et al. 1984, Couch \& Harshbarger 1985, Hawkins et al. 1985, Hinton et al. 1988), 9 mo PT (which was ca 12 mo after initial exposure) should have provided adequate time for the appearance of neoplastic or preneoplastic lesions in affected livers. These lesions were not observed in any fish after transfer to clean water, which indicates that the toxicant causing NLD is most likely not a strong hepatocarcinogen, at least for Atlantic salmon.

Lesions consistent with NLD were observed in all 3 salmonid fishes examined. The pattern and cellular changes appeared similar in all 3 , but the severity and prevalence of lesions were greater in Atlantic salmon (Table 1). Of the 2 groups of chinook salmon maintained at Site III, only the small fish group was affected. This suggests that, at least for chinook salmon, small fish are more sensitive to the disease than large fish. Based on results from herring and shiner perch, non-salmonid fishes appear to be resistent to NLD.

The source and identity of the presumed water-borne toxicant have yet to be determined, and extensive chemical analysis of affected Atlantic salmon tissues, water, and sediment from around the pens indicated no significant chemical contamination (Johnson 1988). The Port Townsend Paper mill is the only source of significant discharge into the bay. However, this is apparently not the source of the toxicant because Atlantic salmon exposed to $30 \%$ effluent from the mill in a bioassay conducted for 4 mo showed no histological signs of NLD (Kent \& Elston 1989). 
Observations of the disease at several locations in British Columbia indicate that unknown toxicant causing NLD is widespread in the Pacific Northwest. These sites in British Columbia are located in apparently unpolluted areas. This observation, and the lack of significant levels of identifiable anthropogenic contaminants in Port Townsend Bay (Johnson 1988), suggest that the cause of NLD may be a natural toxin.

Megalocytosis, the hallmark of NLD, has been induced experimentally in fishes by exposure to a variety of chemical agents including polychlorinated biphenyls (Hinton et al. 1978), endrin (Eller 1971), and nitrosamines (Stanton 1965, Ashley \& Halver 1968). The condition has also been observed in wild fishes from polluted waters (Myers et al. 1987, Peters et al. 1987). Aflatoxin and pyrrolizidine alkaloids (PAs) are natural compounds that are potent inducers of megalocytosis in fishes (Wales 1967, Hendricks et al. 1981) and mammals (Butler 1964, McLean 1970, Dix 1984, Maddocks 1986). There are similarities between the NLD and liver disease caused by PAs. Hendricks et al. (1981) experimentally induced liver lesions in rainbow trout, Salmo gairdneri, with PAs. As typical of NLD, livers of exposed trout exhibited megalocytosis, hepatic necrosis and bile duct proliferation, and affected livers often appeared shriveled, mottled, and yellow (Hendricks et al. 1981). PAs occur in several terrestrial plants and they often cause liver disease in domestic herbivores (McLean 1970, Maddocks 1986). To date, however, PAs have not been reported from the aquatic environment.

Aflatoxin B1 is an unlikely cause of NLD. It is a potent hepatocarcinogen of salmonids, particularly in rainbow trout (Wolf \& Jackson 1967, Wales 1970), but no neoplasms or preneoplastic lesions have been associated with NLD. Furthermore, aflatoxin is usually associated with feed contaminated with Aspergillus fungus, and Kent et al. (1988) demonstrated that NLD was not related to diet.

Our present hypothesis is that the agent may be a phytotoxin from algae. Algal blooms are common at the affected sites and the disease invariably occurs during summer, when these blooms are most prevalent. Several species of marine planktonic algae have been associated with mortalities in pen-reared salmonid fishes in North America and Europe (Gaines \& Taylor 1986 , Tangen 1988). When pathological descriptions were included, they usually indicated that the fish succumbed to gill damage. Liver damage in pen-reared Atlantic salmon was associated with a bloom of a Chattonella-like alga in Loch Triven, Scotland (Tett 1980), and recently, T. Poppe, (National Veterinary Institute, Oslo, Norway, pers. comm.), observed hepatic necrosis in pen-reared Atlantic salmon in association with blooms of Gyrodineum aureoleum. However, mega- locytosis apparently were not a hallmark of these liver diseases. We are continuing to investigate the source and identity of the unknown toxicant. To this end, we will compare algae occurring at affected and unaffected sites in attempt to identify algae associated with the diseae. Additionally, we will conduct bioassays with liver and algal extracts from affected fish in an attempt to identify the chemical nature of the toxicant.

Acknowledgements. This study was partially supported by the Washington Department of Ecology, under contract number 14500. I also thank Drs T P. T Evelyn, J. W. Fournie, L. Margolis and M. S. Myers for helpful suggestions, the staff at Paradise Bay Co. for their cooperation, and J. W. Bagshaw and M. $T$ Wilkinson for histological preparations.

\section{LITERATURE CITED}

Ashley, L. M., Halver, J. E. (1968). Dimethylnitrosamineinduced hepatic cell carcinoma in rainbow trout. J. Natl Cancer Inst. 41: 531--552

Butler, W. H. (1964). Acute toxicity of aflatoxin B in rats. Br. J. Cancer 18: 756-762

Couch, J. A., Harshbarger, J. C. (1985). Effects of carcinogenic agents on aquatic animals: an environmental and experimental overview. Envir. Carcinogenesis Rev. 3: 63-105

Dix, K. M. (1984). The development of hepatocellular tumours following aflatoxin $\mathrm{B}_{1}$ exposure of the partially hepatectomised mouse. Carcinogensis 5: 385-390

Eller, L. L. (1971). Histopathological lesions in cutthroat trout (Salmo clarki) exposed chronically to the insecticide endrin. Am. J. Path. 64: 321-336

Gaines, G., Taylor, F. J. R. (1986). A mariculturists's guide to potentially harmful marine phytoplankton of the Pacific Coast of North America. Marine Resources Sec., Fisheries Branch, British Columbia Ministry of Environ, Information Report 10

Hawkins, W E., Overstreet, R. M., Fournie, J. W., Walker, W. W. (1985). Development of aquarium fish models for environmental carcinogenesis: tumor induction in seven species. J. appl. Toxic. 5: 261-264

Hendricks, J. D. (1982). Chemical carcinogenesis in fish. In: Weber, L. J. (ed.) Aquatic toxicology, Vol. I. Academic Press, New York, p. 149-211

Hendricks, J. D., Meyers, T. R., Shelton, D. W (1984). Histological progression of hepatic neoplasia in rainbow trout (Salmo gairdneri). In: Hoover, K. L. (ed.) Use of small fish species in carcinogenicity testing. Nat. Cancer Inst. Monograph 65. U.S. Government Printing Off., Washington, D.C., p. 321-336

Hendricks, J. D., Sinnhuber, R. O., Henderson, M. C., Buhler, D. R. (1981). Liver and kidney pathology in rainbow trout (Salmo gairdneri) exposed to dietary pyrrolizidine (Senecio) alkaloids. Expl. mol. Path. 35: 170-183

Hinton, D. E., Couch, J. A., Teh, S. J., Courtney, L. A. (1988) Cytological changes during progression of neoplasia in selected fish species. Aquat. Toxic. 11. 77-112

Hinton, D. E., Klaunig, J. E., Lipsky, M. M. (1978). PCBinduced alterations in teleost liver: A model for environmental disease in fish. Mar Fish. Rev. 40: 47-50

Humason, G. L. (1979). Animal tissue techniques. W. H. Freeman Co. San Francisco

Johnson, A. (1988). Port Townsend pen-reared salmon mortal- 
ity; results of screening surveys for toxic chemical in tissues, sediments, seawater, and effluents OctoberDecember 1987. Washington State Dept. Ecology, Olympia, Washington, Seg. N. 09-17-01, p. 1-33

Kent, M. L. Elston, R. A. (1989). Toxicopathic liver disease of pen-reared salmon in Port Townsend Bay - 1988 studies. Washington State Department of Ecol, Olympia, Washington. Tech. Rep. 14500, p. 1-21

Kent, M. L., Myers, M. S., Hinton, D. E., Eaton, W. D., Elston, R. A. (1988). Suspected toxicopathic hepatic necrosis and megalocytosis in pen-reared Allantic salmon Salmo salarin. Puget Sound, Washington, USA. Dis. aquat. Org. 4: 91-100

Luna, L. G. (1968). Armed Forces Institute of Pathology. Manual of histological staining. McGraw-Hill, New York

Maddocks, A. R. (1986). Chemistry and toxicology of pyrrolizidine alkaloids. Academic Press, Hardcourt Brace Jovanovich, Montreal

McLean, E. K. (1970). The toxic actions of pyrrolizidine (Senecio) alkaloids. Pharmac. Rev. 22: 429-483

Myers, M. S., Rhodes, L. D., McCain, B. B. (1987). Pathologic anatomy and patterns of occurrence of hepatic neoplasms, putative preneoplastic lesions, and other idiopathic hepatic conditions in English sole (Parophrys vetulus) from Puget Sound, Washington. J. Natl Cancer Inst. 78: 333-363

Peters, N., Köhler, A., Kranz, H. (1987). Liver pathology in fishes from the Lower Elbe as a consequence of pollution. Dis. aquat. Org. 2: 87-97

Responsible Subject Editor: Dr G. Peters, Hamburg, F. R. Geimany
Sinnhuber, R. O., Hendricks, J. D., Wales, J. H., Putnam, G. B. (1977). Neoplasms in rainbow trout, a sensitive animal model for environmental carcinogenesis. Ann. N. Y Acad. Sci. 298: 389-408

Stanton. M. F. (1965). Diethylnitrosamine-induced hepatic degeneration and neoplasia in the aquarium fish, Brachydanio rerio. J. Natl Cancer Inst. 43: 117-134

Tangen, K. (1988). Harmful algal blooms in Northern Europe: their causes and effects on mariculture. Aqua Nor 1987. Int. Conf., Tronheim, Norway, p. 29-33

Tett, P. (1980). Phytoplankton and the fish kills in Loch Striven Scottish Mar. Biol. Ass., Internal Rep. No. 25., Oban, Argyll, Scotland, p. 1-110

Wales, J. H. (1967). Degeneration and regeneration of liver parenchyma accompanying hepatogenesis. In: Halver, J. E., Mitchell, I. A. (eds.) Trout hepatoma research conference papers, research report 70. Bureau of Sport Fisheries and Mildlife, Washington, D.C., p. 56-59

Wales, J. H. (1970). Hepatoma in rainbow trout. In: Snieszko, S. F. (ed.). A symposium on diseases of fishes and shellfishes. Am. Fish. Soc., Spec. Publ. No. 5., p. 351-365

Wolf, H., Jackson, E. W. (1967). Hepatoma in salmonids the role of cottonseed products and species differences. In: Halver, J. E., Mitchell, I. A. (eds.) Trout hepatoma research conference papers, research report 70. Bureau of Sport Fisheries and Wildlife, Washington, D.C., p. $29-33$

Manuscript first received: June 21, 1989

Revised version accepted: December 14, 1989 